\title{
Seroprevalence and Molecular Detection of Bovine Brucellosis
}

Raghavendra Prasad Mishra ${ }^{1}$, Udit Jain ${ }^{1}$, Barkha Sharma ${ }^{2}$, Kaushal Kusum $^{3}$, Neha Singh ${ }^{4}$

10.18805/IJAR.B-4724

\begin{abstract}
Background: Brucellosis is one of the major zoonotic problems that exist worldwide. Brucellosis is clinically characterized by metritis, mastitis, repeat breeding, abortion in the last trimester of pregnancy, retention of placenta and reduced milk production in the female whereas epididymitis, orchitis and sterility in male. In humans can be highly variable, ranging from nonspecific, flu-like symptoms to undulant fever, arthritis, orchitis and epididymitis.

Methods: A total of 567 bovine serum samples was taken from four districts of Brij region of UP. All the samples were processed to detection of prevalence of brucellosis by RBPT, STAT ELISA and confirmation of genes bcsp31, 16SrRNA, omp2 and IS711 by PCR. Result: The prevalence of brucellosis was found to be $07.93 \%$ (31/391), 08.69\% (34/391) and 10.74\% (42/391) shows positive by RBPT, STAT and I- ELISA respectively. In buffalo Out of 176 tested serum sample the seroprevalence was found to be $09.66 \%$ (17/ 176), $10.79 \%$ (19/176) and 12.5\% (22/176) positive by RBPT, STAT and I- ELISA respectively. Out of 567 samples 18 were positive for Brucella genus specific gene. The higher prevalence of the disease in this region increases the risk of zoonotic transmission and it implies a serious threat to the human population as well as the huge impact on economy due to loss of productivity as well as loss of livestock population.
\end{abstract}

Key words: Bovine serum, I- ELISA, PCR, RBPT, STAT.

\section{INTRODUCTION}

Brucellosis is one of the world's major zoonotic problems that exist worldwide and is more or less endemic in most African countries and still exists in some southern European countries. Though it has been eradicated in many developed countries in Europe, Australia, Canada, Israel, Japan and New Zealand (Geering et al., 1995) but it remains an uncontrolled problem in regions of high endemicity such as the Africa, Mediterranean, Middle East, parts of Asia and Latin America (Refai, 2002). Almost all domestic species can be affected with brucellosis except cats which are resistant to Brucella infection (CFSPH, 2003). Brucellosis is transmitted from mother to offspring before or at the birth, through milk, by sexual contact, direct physical contact, from polluted environments and from eating spoiled raw meat mainly placenta and birth products. Brucellosis is clinically characterized by metritis, mastitis, repeat breeding, abortion in the last trimester of pregnancy, retention of placenta and reduced milk production in the female whereas epididymitis, orchitis and sterility in male (Radostits et al., 2000). Brucellosis is caused by members of genus Brucella. These are small, non-motile, aerobic, facultative intracellular, gramnegative coccobacilli. The ability of Brucella to replicate and persist in host cells is directly associated with its capacity to cause persistent disease and to circumvent innate and adaptive immunity (Fichi, 2003). The species of Brucella and their major hosts are Br. abortus (cattle), Br. melitensis (goats), Br. suis (swine) and Br. ovis (sheep). Br.abortus also causes infection in horses and is commonly found in chronic bursal enlargements as a secondary invader rather than a primary pathogen (Radostits et al., 2000). In humans, brucellosis is considered to be an occupational disease that mainly affects slaughter house workers, butchers and
${ }^{1}$ Department of Veterinary Public Health, College of Veterinary Sciences and Animal Husbandry, U.P. Pt. Deen Dayal Upadhyaya Veterinary Science University, Mathura-281 001, Uttar Pradesh, India.

2Department of Veterinary Epidemiology and Preventive Medicine, College of Veterinary Sciences and Animal Husbandry, DUVASU, Mathura-281 001, Uttar Pradesh, India.

${ }^{3}$ Department of Veterinary Gynaecology and Obstetrics, Mahatma Jyotiba Fule College of Veterinary and Animal Science, Chomu, Jaipur-303 702, Rajasthan, India.

${ }^{4}$ Department of Veterinary Microbiology, Mahatma Jyotiba Fule College of Veterinary and Animal Science, Chomu, Jaipur-303 702, Rajasthan, India.

Corresponding Author: Raghavendra Prasad Mishra, Department of Veterinary Public Health, College of Veterinary Sciences and Animal Husbandry, U.P. Pt. Deen Dayal Upadhyaya Veterinary Science University, Mathura-281 001, Uttar Pradesh, India. Email: rmishra523@rediffmail.com

How to cite this article: Mishra, R.P., Jain, U., Sharma, B., Kusum, K. and Singh, N. (2022). Seroprevalence and Molecular Detection of Bovine Brucellosis. Indian Journal of Animal Research. DOI: $10.18805 /$ IJAR.B-4724.

Submitted: 16-07-2021 Accepted: 07-12-2021 Online: 07-01-2022

veterinarians. Symptoms in human brucellosis can be highly variable, ranging from non-specific, flu-like symptoms (acute form) to undulant fever, arthritis, orchitis and epididymitis (Hassan et al., 2012). Bovine brucellosis, mainly caused by Brucella abortus, is an important zoonotic disease leading to several public health and economic problems in endemic areas. 


\section{MATERIALS AND METHODS}

\section{Source and place of samples collection}

The present study was conducted in four districts viz., Mathura, Agra, Hathras and Kasganj from August, 2017 to April, 2019. These districts were selected because of the high numbers of smallholder dairy farmers, gaushalas and good animal husbandry practices. During the present study, about $10 \mathrm{ml}$ of blood from each animal and total 567 sample (391 cattle and 176 buffalo serum sample) were collected in aseptic conditions using labeled sterile disposable syringes (dispovan) or vacutainers (BD, USA). All the samples were processed in the department of veterinary public health, college of veterinary science and animal husbandry, Mathura, U.P. The serum was separated after clotting of blood and transported to laboratory on ice. All the serum samples were stored at $-20^{\circ} \mathrm{C}$ till tested.

\section{Prevalence based on different serological tests}

Rose bengal plate test (RBPT) and standard tube agglutination test (STAT) antigen were procured from Indian Veterinary Research Institute, (IVRI), Izatnagar, India. For serum I-ELISA, kit was procured from Svanova (Biotech$A B)$, Uppasala, Sweden. RBPT antigen is a $8 \%$ suspension of pure smooth killed cells of Brucella abortus strain 99 phenolised and stained with rose Bengal dye. Rose Bengal Plate Test is a single dilution serum agglutination test. It was performed on glass slides according to the method presented by (Alton et al.,1988). To detection of STAT in a serum samples, Brucella abortus plain antigen were taken which was heat killed phenolised suspension of Brucella abortus strain 99 and it show $50 \%$ agglutination at $1 / 500$ final dilution of serum with Indian standard. In bovine serum samples antibody was detected by Indirect ELISA (I-ELISA) kit procured from Svanova (Biotech-AB), Uppasala, Sweden. Briefly, each of the kit contained 96 flat bottom polystyrene with Brucella abortus precoated antigen wells.

\section{Molecular characterization of Brucella by PCR}

Bacterial DNA was extracted by Thermo scientific Gene JET Whole Blood Genomic DNA purification kit. For the PCR reaction, $\mathrm{PCR}$ master mix solution (Genei, Bangalore) was used. DNA isolation and PCR analysis for detection of bcsp31, omp2, 16S rRNA and IS711 gene was carried out as per the method described by Baily et al. (1992), Klevezas et al. (1992), Romero et al. (1995) and Doust et al. (2007) respectively (Table 1). PCR was carried out in a final reaction volume of $25 \mu \mathrm{l}$ containing $12.5 \mu \mathrm{l}$ of Master mix, $3 \mu \mathrm{l}$ of DNA template, $1 \mu$ of each of the primers (forward and reverse) with concentration of $15 \mathrm{pmol}$ each and rest of DNAse free water. For bcsp31 gene amplification an initial denaturation step at $95^{\circ} \mathrm{C}$ for $4 \mathrm{~min}$, denaturation at $94^{\circ} \mathrm{C}$ for 2 min., annealing $65^{\circ} \mathrm{C}$ for 2 minute, extension $72^{\circ} \mathrm{C}$ for $1.5 \mathrm{~min}$. and followed by a final extension step at $72^{\circ} \mathrm{C}$ for $2.5 \mathrm{~min}$. For omp2 gene amplification an initial denaturation step at $94^{\circ} \mathrm{C}$ for $4 \mathrm{~min}$, denaturation at $94^{\circ} \mathrm{C}$ for $1 \mathrm{~min}$., annealing $60^{\circ} \mathrm{C}$ for 1 minute, extension $72^{\circ} \mathrm{C}$ for $1 \mathrm{~min}$. and followed by a final extension step at $72^{\circ} \mathrm{C}$ for $3 \mathrm{~min}$. For $16 \mathrm{~S}$ rRNA gene amplification an initial denaturation step at $95^{\circ} \mathrm{C}$ for $5 \mathrm{~min}$, denaturation at $94^{\circ} \mathrm{C}$ for $5 \mathrm{~min}$., annealing $54^{\circ} \mathrm{C}$ for 1.5 minute, extension $72^{\circ} \mathrm{C}$ for $1.5 \mathrm{~min}$. and followed by a final extension step at $72^{\circ} \mathrm{C}$ for 6 min.For bcsp 31 gene amplification an initial denaturation step at $95^{\circ} \mathrm{C}$ for $4 \mathrm{~min}$, denaturation at $94^{\circ} \mathrm{C}$ for $2 \mathrm{~min}$., annealing $65^{\circ} \mathrm{C}$ for 2 minute, extension $72^{\circ} \mathrm{C}$ for $1.5 \mathrm{~min}$. and followed by a final extension step at $72^{\circ} \mathrm{C}$ for $2.5 \mathrm{~min}$. For IS711 gene amplification an initial denaturation step at $95^{\circ} \mathrm{C}$ for $10 \mathrm{~min}$, denaturation at $94^{\circ} \mathrm{C}$ for $1 \mathrm{~min}$., annealing $58^{\circ} \mathrm{C}$ for 1 minute, extension $72^{\circ} \mathrm{C}$ for $1 \mathrm{~min}$. and followed by a final extension step at $72^{\circ} \mathrm{C}$ for 7 minute. For each gene 35 amplification cycles were performed.After the amplification, amplicons were separated in $1.5 \%$ gel intris-acetate EDTA (TAE) buffer at 60 volt for $80 \mathrm{~min}$, stained with $0.5 \%$ ethidiumbromide solution and visualized under ultraviolet light.

\section{RESULTS AND DISCUSSION}

Out of 391 tested cattle serum sample, the seroprevalence of brucellosis was found to be $07.93 \%$ (31/391), 08.69\% (34/391) and $10.74 \%$ (42/391) shows positive by RBPT, STAT and I- ELISA respectively. In buffalo Out of 176 tested serum sample the seroprevalence was found to be $09.66 \%$ (17/ 176), $10.79 \%$ (19/176) and $12.5 \%$ (22/176) positive by RBPT, STAT and I- ELISA respectively. The result showed that the seroprevalence of brucellosis in buffalo was significantly higher than seroprevalence of brucellosis in cattle.

The seroprevalence of brucellosis was higher in buffalo as compare to cattle (Table 2 ) but significantly the prevalence in bovine brucellosis not differ $(p=0.541)$. In present study

Table 1: Details of primers used for PCR reaction for Brucella genes.

\begin{tabular}{|c|c|c|c|}
\hline $\begin{array}{l}\text { Gene target and size of } \\
\text { Amplified product (bp) }\end{array}$ & Primers & Sequences $\left(5^{\prime}-3^{\prime}\right)$ & Reference \\
\hline \multirow[t]{2}{*}{ bcsp31 (223bp) } & B4 (Forward) & 5'-TGG-CTC-GGT-TGC-CAA-TAT-CAA-3' & Baily et al. (1992) \\
\hline & B4 (Reverse) & 5'-CGC-GCT-TGC-CTT-TCA-GGT-CTG-3' & \\
\hline \multirow[t]{2}{*}{ omp2 (193bp) } & JPF (Forward) & 5'-GCG-CTC-AGG-CTG-CCG-ACG-CAA-3' & Klevezas et al. (1992) \\
\hline & JPF (Reverse) & 5'-ACC-AGC-CAT-TGC-GGT-CGG-TA-3' & \\
\hline \multirow[t]{2}{*}{ 16S rRNA (905) } & Forward & 5'-TCG-AGC-GCC-CGC-AAG-GG-3' & Romero et al. (1995) \\
\hline & Reverse & 5'-AAC-CAT-AGT-GTC-TCC-ACT-AA-3' & \\
\hline \multirow[t]{2}{*}{ IS711 (498bp) } & IS711AB (Forward) & 5'-GAC-GAA-CGG-AAT-TTT-TCC-AAT-CCC-3' & Doust et al. (2007) \\
\hline & IS711AB (Reverse) & 5'-TGC-CGA-TCA-CTT-AAG-GGC-CTT-CAT-3' & \\
\hline
\end{tabular}


the sero-prevalence of brucellosis in cattle and buffalo by I-ELISA was $10.74 \%$ and $12.5 \%$ respectively in serum samples. Present finding were very close to the reports of Kebede et al. (2008) (11\%), Eshetu et al. (2005) (10\%) and $9.7 \%$ by Aggad and Boukraa, (2006). Higher prevalence rates were also reported in cattle in Nigeria (32.2\%) (Junaidu et al., 2008), Berhe et al. (2007) (42.31\%) and Kebede et al. (2008) (45.9\%) in Ethiopia, Aggad and Boukraa (2006) $(31.5 \%)$ in Algeria and Ahmad, (2009) (25.8\%) in Jordan. Some lower prevalence rate was reported by Kassahun (2004) for intensive (2.5\%) and extensive farms $(1.7 \%)$ in Southern Ethiopia, Algeria Berhe et al. (2007) (3.19\%) in extensive production systems (Fig 1,2,3).

\section{Molecular detection}

In this study, primers B4/B5, F4/R2, JPF/JPR for Brucella genus detection and IS711ABF/ IS711ABR for Brucella species detection were used. These primer pairs encode fragments $223 \mathrm{bp}, 905 \mathrm{bp}, 193 \mathrm{bp}$ and $498 \mathrm{bp}$ of the genes bcsp31, 16SrRNA, omp2 and IS711 genes respectively and was able to identify genus Brucellaand species Brucella abortus. The aim of this study was to evaluate and compare three pairs of primers, which are broadly used for diagnosis of brucellosis cattle and buffalo serum samples. A total of 567 samples were screened by PCR to detect the presence of Brucella genus specific gene (bcsp31, omp2 and 16S rRNA) and Brucella abortus species specific IS711genes. Out of 567 samples 18 were positive for Brucella genus specific gene. Out of 18 bovine serum PCR positive sample, 6 sample were positive for bcsp31, omp2 and 16S rRNA gene, 8 sample were positive for bcsp31 and omp2 gene and 4 serum samplewere positive for bcsp 31 and 16S rRNA gene. All bcsp31, omp2 and 16S rRNA gene were show positive for Brucella species specific IS711 (498 bp) genes. Out of four human DNA sample one positive for bcsp31, omp2 and 16S rRNA gene, 2 sample shows positive for bcsp31 and 16S rRNA gene and one sample positive for bcsp31 and omp2 gene. The bcsp31 PCR was the most sensitive (Mukherjee et al., 2005). Some modification in PCR protocol the sensitivity of the detection can also be affected (Romero et al., 1995; Leal-Klevezas et al., 1995). Variation in the omp2 gene sequence has been used as a basis for typing strains (Bardenstein et al.,2002; Ferrao et al., 2006). Some other researcher also developed PCR based assays for the identification of the genus Brucella from animal milk, blood, serum, tissue and from human blood and serum, these employ the gene encoding the $31 \mathrm{kDa}$ Brucella cell surface salt extractable protein (BCSP), omp2, 16S rRNA, IS711 and other gene targets (Da Costa et al.,1996; Rijpens et al., 1996; Bricker, 2002; Morata et al.,2003; Mukherjee et al., 2005; Leary et al., 2006). Finally it cannot be ruled out that the bcsp31 gene sequence is better conserved than the omp2 and $16 \mathrm{~S}$ rRNA gene sequence in the genus Brucella. The better molecular diagnostic approach for screening of field animals and for increased sensitivity and higher specificity, more than one marker-based PCR could be use.

Table 2: Species wise seropositivity of bovine brucellosis (cattle and buffalo) detected by RBPT, STAT and I-ELISA.

\begin{tabular}{|c|c|c|c|c|c|c|c|c|}
\hline Species & $\begin{array}{l}\text { No. of } \\
\text { serum } \\
\text { sample }\end{array}$ & $\begin{array}{c}\text { No. of } \\
\text { samples positive } \\
\text { by RBPT }\end{array}$ & $\begin{array}{l}\text { Percent } \\
\text { positivity } \\
\text { by RBPT }\end{array}$ & $\begin{array}{c}\text { No. of } \\
\text { samples positive } \\
\text { by STAT }\end{array}$ & $\begin{array}{l}\text { Percent } \\
\text { positivity } \\
\text { by STAT }\end{array}$ & $\begin{array}{c}\text { No. of } \\
\text { samples positive } \\
\text { by I-ELISA }\end{array}$ & $\begin{array}{c}\text { Percent } \\
\text { positivity } \\
\text { by I-ELISA }\end{array}$ & $p$ value \\
\hline Cattle & 391 & 31 & $07.93 \%$ & 34 & $08.69 \%$ & 42 & $10.74 \%$ & 0.541 \\
\hline Buffalo & 176 & 17 & $09.66 \%$ & 19 & $10.79 \%$ & 22 & $12.5 \%$ & \\
\hline Total & 567 & 48 & $08.46 \%$ & 53 & $09.35 \%$ & 64 & $11.28 \%$ & \\
\hline
\end{tabular}

$p>0.05$ at $5 \%$ level of significance.

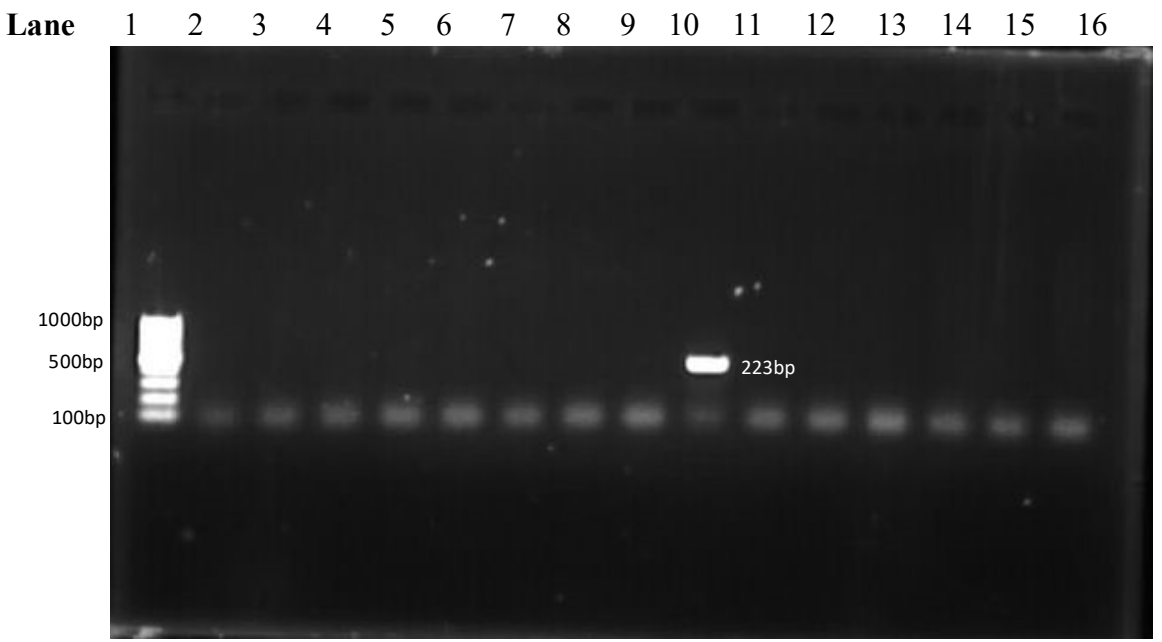

Fig 1: Agarose gel showing PCR amplified product for Brucella genus specific gene isolated from bovine serum sample. Lane: 1: 100 bp DNA Ladder; Lane: 10: bcsp 31 gene. 


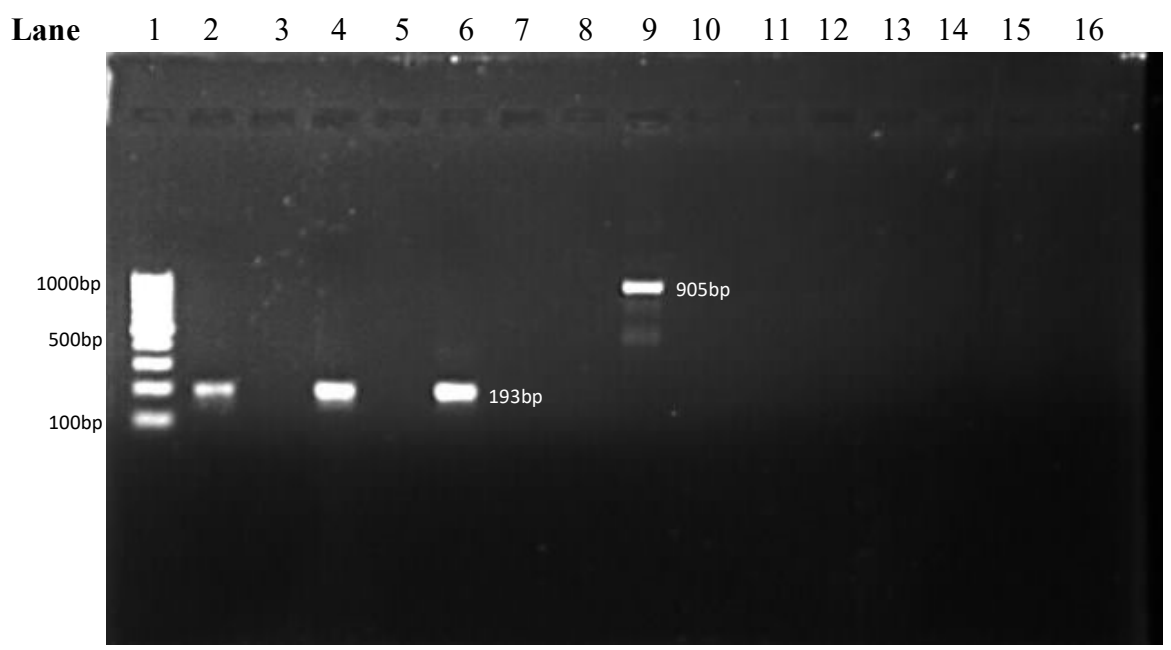

Fig 2: Agarose gel showing PCR amplified product for Brucella genus specific genes isolated from bovine serum sample. Lane 1: 100 bp DNA Ladder; Lane 9: 16S rRNA gene; Lane 2, 4, 6: omp2 gene.

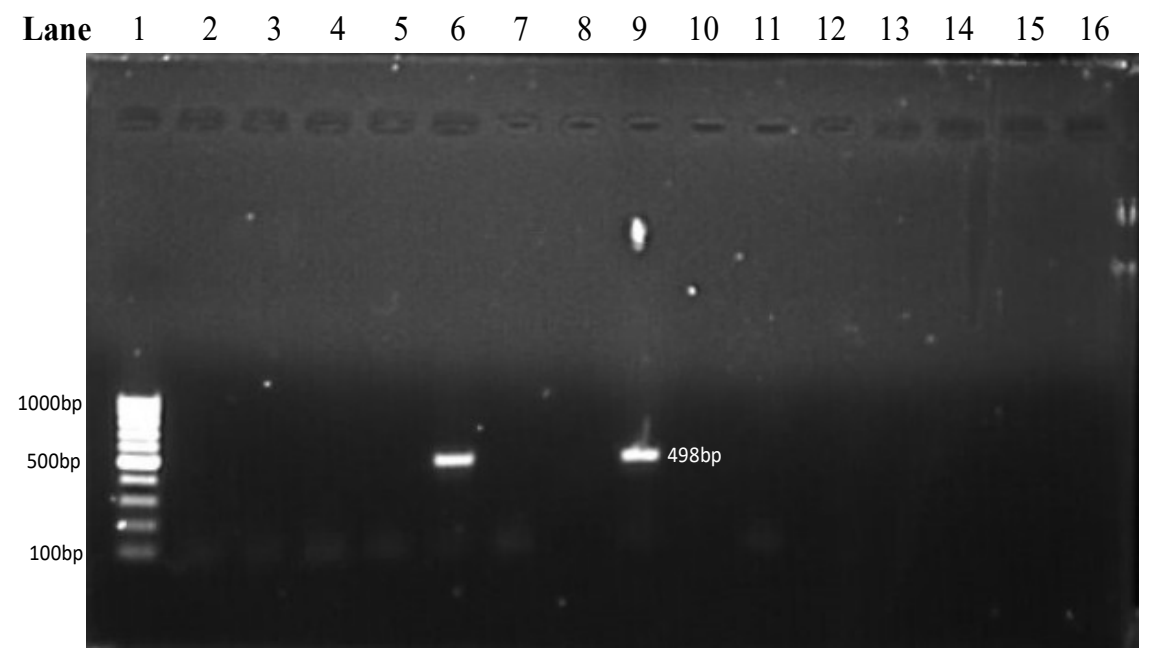

Fig 3: Agarose gel showing PCR amplified product for Brucella species specific genes isolates from bovine serum sample. Lane 1: 100 bp DNA Ladder; Lane 6 and 9: IS711 gene.

\section{CONCLUSION}

Out of 567 bovine serum sample, the prevalence of brucellosis in 391 cattle was found to be $07.93 \%$ (31/391), $08.69 \%$ (34/ $391)$ and $10.74 \%$ (42/391) shows positive by RBPT, STAT and I- ELISA respectively and in 176 buffalo tested serum sample the seroprevalence was found to be $09.66 \%$ ( $17 /$ $176), 10.79 \%$ (19/176) and $12.5 \%$ (22/176) positive by RBPT, STAT and I- ELISA respectively. 18 samples were positive in molecular detection by PCR. The higher prevalence of the disease in this region increases the risk of zoonotic transmission and it implies a serious threat to the human population as well as the huge impact on economy due to loss of productivity as well asloss of livestock population.

\section{ACKNOWLEDGEMENT}

The authors are highly thankful to Indian Council of Agricultural Research, New Delhi and Dean, College of Veterinary Science and Animal Husbandry, Uttar Pradesh
Pandit Deen Dayal Upadhayay Pashu Chikitsa Vigyan Vishvidhyalaya Ewam Go-Anusandhan Sansthan (DUVASU), Mathura, U.P., India, for providing necessary funds and facilities to carry out the investigations.

\section{REFERENCES}

Aggad, H. and Boukraa, L. (2006). Prevalence of bovine and human brucellosis in western Algeria: Comparision of screening tests. Eastern Mediterranean Health Journal. 12: 119-128.

Alton, G.G., Jones, L.M., Angus, R.D. and Verger, J.M. (1988). Techniques for the Brucellosis Laboratory ( $2^{\text {nd }}$ edn.), INRA, Paris, France.

Ahmed, A.M. (2009). Seroprevalence of cattle brucellosis in Gabiley District, Somaliland. Master's Thesis submitted to Sheikh Technical Veterinary School, Somaliland.

Baily, G.G., Krahn, J.B., Drasar, B.S. and Stoker, N.G. (1992). Detection of Brucella melitensis and Brucella abortus by DNA amplification. American Journal of Tropical Medicine and Hygiene. 95: 271-275. 
Bardenstein, S., Mandelboim, M., Ficht, T.A., Baum, M. and Banai, M. (2002). Identification of the Brucella melitensis vaccine strain Rev. 1 in animals and humans in Israel by PCR analysis of the Pstl site polymorphism of its omp2 gene. Journal of Clinical Microbiology. 40: 1475-1480.

Berhe, G., Belihu, G. and Asfaw, A. (2007). Seroepidemiological investigation of bovine brucellosis the extensive cattle production system of Tigray Region of Ethiopia. International Journal of Applied Research in Veterinary Medicine. 5: 265-70.

Bricker, B.J. (2002). PCR as a diagnostic tool for brucellosis. Veterinary Microbiology. 90: 435-446.

Costa, D., M., Guillou, J.P., Garin-Bastuji, B., Theibaud, M. and Dubray, G. (1996). Specificity of six gene sequences for the detection of the genus Brucella by DNA amplification. Journal of Appllied Bacteriology. 81: 267-275.

Center for Food Security and Public Health (2003). Doust, S.R.H., Ahmad, Z., Ahamdi, A., Hajia, M., Izadi, M. and Mobarez, A.M. (2007). Detection of Brucella abortus by alkB and IS711 based primers. Journal of Research in Medical Science. 12(2): 62-67.

Eshetu, Y., Kassahun, J., Abebe, P., Beyene, M., Zewdie, B. and Bekele, A. (2005). Seroprevalence study of brucellosis Trop Anim Health Prod on dairy cattle in Addis Ababa. Bulletin of Animal Health and Productionin Africa. 53: 211214.

Ferrao-Beck, L., Cardoso, R. and Munoz, P.M. (2006). Development of a multiplex PCR assay for polymorphism analysis of Brucella suis biovars causing brucellosis in swine. Veterinary Microbiology. 115: 269-277.

Fichi, T.A. (2003). Intracellular survival of Brucella: Defining the link with persistence. Veterinary Microbiology. 92: 213-223.

Geering, W.A., Forman, J.A. and Nunn, M.J. (1995). Exotic Diseases of Animals, Aust. Gov. Publishing Service, Canberra, Australia.

Hassan, M., Mai Peter, C., Kabir, I.J. and Peter, N.T. (2012). A large seroprevalence survey of brucellosis in cattle herds under diverse production systems in northern Nigeria. BMC Veterinary Research. 8: 144-152.

Junaidu, A.U., Oboegbulem, S.I. and Salihu, M.D. (2008). Serological survey of Brucella antibodies in breeding herds. Journal of Microbiology and Biotechnology Research. 1: 60-65.
Kassahun, A. (2004). Epidemiology of brucellosis in cattle and its seroprevalence in animal health professionals in Sidama Zone, Southern Ethiopia. Master's Thesis, FVM, AAU, Debre Zeit, Ethiopia.

Kebede, T., Ejeta, G. and Ameni, G. (2008). Seroprevalence of bovine brucellosis in small holder farms in central Ethiopia (Wuchale-Jida district). Revue de Medecine Veterinaire. 159: 3-9.

Klevezas, L.D.S., Martinez-Vaquez, I.O., Lopez-Merino, A. and Martinez-Soriano, J.P. (1992). Single-step PCR for detection of Brucella spp. from blood and milk of infected animals. Journal of Clinical Microbiology. 33: 087-3090.

Leary, O.S., Michael, S. and Torres, S. (2006). Brucella abortus detection by PCR assay in blood, milk and lymph tissue of serologically positive cows. Research in Veterinary Science. 81: 170-176.

Leal-Klevezas, D.S., Merino, L.A. and Soriano, M.J.P. (1995). Molecular detection of Brucella species: Rapid identification of B. abortus biovar I using PCR. Archives of Medical Research. 26(3): 263-67.

Morata, P., Maria I., Queipo, O. and Juan, D.C. (2003). Development and Evaluation of a PCR-Enzyme-Linked Immunosorbent Assay for Diagnosis of Human Brucellosis. Journal of Clinical Microbiology. 41(1): 144-148.

Mukherjee, F., Jain, J., Patel, V. and Nair, M. (2005). Multiple genusspecific markers in PCR assays improve the specificity and sensitivity of diagnosis of brucellosis in field animals. Journal of Medical Microbiology. 56: 1309-1316.

Radostits, O.M., Gay, C.C., Blood, D.C. and Hinchliff, K.W. (2000). Veterinary Medicine: A Text Book of Diseases of Cattle, Sheep, Pigs, Goats and Horses. $9^{\text {th }}$ edition. 867-881.

Refai, M. (2002). Incidence and control of brucellosis in the Near East region. Veterinary Microbiology. 90: 81-110.

Rijpens, N.P., Jannes, G., Asbroeck, M.V., Rossau, R. and Herman L.M.F. (1996). Direct detection of Brucella spp. in raw milk by PCR and reverse hybridization with 16S-23S rRNA spacer probes. Applied Environmental Microbiology. 62: 1683-1688.

Romero, C.C., Gamazo, M., Pardo and Lo'pezgon, I. (1995). Specific detection of Brucella DNA by PCR. Journal of Clinical Microbiology. 33: 615-617. 